\title{
咽侯頭異常感の原因的要因と遷延性要因
}

一堠頭マイクロ手術例での検討一

\author{
太田 文彦・米川 紘子
}

\section{Causal Factor and Protracted Factor of an Abnormal Lump Sensation in the Throat}

\section{Fumihiko Ohta and Hiroko Yonekawa}

(Kinki University School of Medicine)

Causal factor and protracted factor are suspected to cause long-standing: abnormal sensation in the throat. Observation were performed before laryngo-microsurgery, immediately after surgery, 3-6 weeks after operation and by "enquete" inquiry. Laryngeal diseases were considered as a causal factor. Abnormal sensation due to laryngeal polyp disappeared soon after surgery, though the sensation continued for several weeks after surgery for Reinke's edema. Laryngeal microsurgery was a causal factor. Abnormal sensation due to laryngo-microsurgery occurred more often in females, and the sensation soon subsided off. Smoking was considered as a causal factor, but not as a delayed factor. Abnormal CMI score was not a delayed factor.

Key words: lump sensation in the throat, laryngo-microsurgery, smoking, CMI, laryngeal polyp

\section{緒言}

咽喉頭異常感（以下異常感之略す）の原因之 して，成書には局所的，全身的，心理的の三つ の要因をあげ，それぞれに多くの病名が羅列さ れている。しかしそれはあくまで原因となりう る病気であって，逆にその病気があれば異常感 が必発するということではない.したがって， それが真に異常感の原因であるかどうかは疑わ しい．現に舌扁桃の肥大があっても異常感を全 く訴え例がある．にもかかわらず置常感を訴 える例でたまたま舌扇桃が少し大きいと，それ を直ちに原因と考えるということはよく見かけ る.
異常感を研筧するにあたり，われわれは異常 感の発来の原因になる病変（原因的要团）のほ かに, 異常感がなかなか消失しない要肉（遷延 性要因）を考えるべきであろうと考えた。そこ で日常䧗床のなかで異常感発来の原因的要因に なる可能がのあるあのとして, 舌根部から下咽 韻・喉䫓にかけてかなりの機械的侵襲を考えね ばなら收䫓マイクロ乎術をとりあげてみた。 この于術の対象になる喉頭吹慗その屯の屯異常 感の原因的要因であるので, 術前の異常感の有 鮦にかかわらず症例をあつめて，その原因と遷 延性要因之考えてみる目的で本研究を計画し た。 


\section{観察方法}

1. 調查対象：昭和60年 1 月より 62 年 7 月の 2 年 7 力月間に喉頭マイクロ手術を行った全症 例から無作為に選んだ 111 例を調查対象とし た。そのうち術前に咽知䫓異常感を泝えたもの 83例, 訴えないもの28例であった。

調查は術前，術後（入院中），退院後 $1 \sim 4$ 週（術後 $3 \sim 6$ 週）の 3 回に行い，さらに術後 3 力月以上経ったものにアンケートによる調查 を行った. アンケート調查の回収率は65.8\%で あった。

2. 対象例の性别, 作榆分乕：表 1 に示すよ うに男60例女51例で，いずれも40才代にピーク を示した。

3. 症例の分類：術前より異常感を訴えたむ のを $\mathrm{A}$ 群, 術前には無かったもをB群, 術後 2 〜3 日以内に異常感を泟えたものを $\mathrm{a}$ 群, 術後 異常感の無かったものを $\mathrm{b}$ 群として，全症例を 表 2 に示す 4 群に分類した。A群83例中62例 (74.7\%) は術後も異常感があり（A a 群)，21. 例 $(25.3 \%)$ は術後置常感が消失した（A b

表 1 年粭・性別

\begin{tabular}{crrr}
\hline & 男性 & 女性 & 計 \\
$10 \sim 19$ 才 & 0 & 1 & 1 \\
$20 \sim 29 \prime \prime$ & 4 & 9 & 13 \\
$30 \sim 39 \prime \prime$ & 10 & 9 & 19 \\
$40 \sim 49 \prime \prime$ & 18 & 17 & 35 \\
$50 \sim 59 \prime \prime$ & 17 & 7 & 24 \\
$60 \sim 69 \prime \prime$ & 7 & 7 & 14 \\
70 才以上 & 4 & 1 & 5 \\
\hline 計 & 60 & 51 & 111
\end{tabular}

表 2 喉頭マイクロ手術と咽喉頭罢常感

\begin{tabular}{lllr}
\hline & 術前 & 術後 & 例数 (男: 女) \\
A a 群 & あり & あり & $62(36: 26)$ \\
A b 群 & あり & なし & $21(14: 7)$ \\
B a 群 & なし & あり & $16(5: 11)$ \\
B b 群 & なし & なし & $12(5: 7)$ \\
\hline 合 計 & & & $111(60: 51)$
\end{tabular}

群)。またB群28例中16例（57.1\%）は術後異 常感を生じ (B a 群)，12例（42.9\%）は術後 も買常感は無かった ( $\mathrm{B}$ b 群).

\section{観察結果}

1. 咨患別にみた㗹頭マイクロ手術前後の異 常感（表 3 ）

喉端マイクロ手術を行った原因矣患別に術前 後の異常感の推移について集計した。

声莎ポリープはA群83例り43例（51.8\%), $\mathrm{B}$ 群 26 例中12例（46.1\%）と有意の差をみと ない。ポリープ㴍望带ではA群22例（26.5\%）, B 群 3 例（11.5\%）と善があるようにみえるが

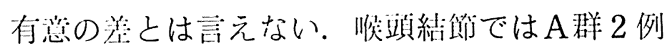
(2.4\%)，B 群 6 例 $(21.4 \%)$ 之危険率 $1 \%$ 以 下で有意の着をみとめ, 䊼啁例では異常感を訴 えるととが少ないと言うことができる.

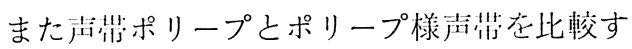
ると，A群では術後異常黛消失した b 群が畒带 ポリープでは14例（32.6\%）であるのに刘して ポリープ㴍声州では 2 例 $(9.1 \%) \quad と 10 \%$ 水準 で有意の睃をみとめた。

\section{2. 哭煙との䦥係（表 4)}

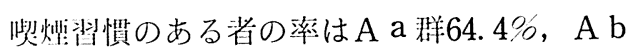
群57.1\%, B a 群50.0\%, B b 群 $41.7 \%$ であっ た. $\mathrm{A}$ 群 $\mathrm{B}$ 群間, $\mathrm{a}$ 群 $\mathrm{b}$ 群間と屯に10\%水準で は有傯の差は㴓めなかった。術後 $3 \sim 6$ 週に異 常感のある43例中喫煙者は27例（62.8\%）で

表 3 堠頭マイクロ手術施行前後の異常感(原疾患別)

\begin{tabular}{|c|c|c|c|c|}
\hline \multirow{2}{*}{ 疾患名 } & \multicolumn{2}{|c|}{$\mathrm{A}$} & \multicolumn{2}{|c|}{ B } \\
\hline & $\mathrm{a}$ & $\mathrm{b}$ & a & $\mathrm{b}$ \\
\hline 声带ポリープ & 29 & 14 & 8 & 4 \\
\hline ポリープ様声帯 & 20 & 2 & 3 & 0 \\
\hline 声带絬瀄 & 2 & 0 & 3 & 3 \\
\hline 唯頭墔胞 & 5 & 2 & 0 & 2 \\
\hline 癌 & 0 & 1 & 0 & 1 \\
\hline ロイコプラキー & 0 & 1 & 1 & 1 \\
\hline 反回祅経脎舫 & 1 & 0 & 1 & 0 \\
\hline その他 & 5 & 1 & 0 & 1 \\
\hline 合 計 & 62 & 21 & 16 & 12 \\
\hline
\end{tabular}


あり, 異常感のない65例のうち喫煙者は36例 (55.4\%) であって, 有意の差は認めない.

アンケート回答でも異常感のある16例中 9 例 (56.3\%)，異常感のない57例中32例（56.1 \%)とほとんど差がない.

\section{CM I との関係（表 5)}

樑町の判定法を用いて, 正常群（I ・ II 領

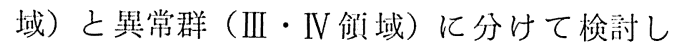
た. A群，B群間にはカイ 2 乘検定で10\%水準 で有意の差がみられ，A群に異常例が多いと言 える. とくにA a 群に異常例が多い.

術後 $3 \sim 6$ 週では, 異常感のある43例中 CM I 異常は12例 (27.9\%)，異常感のない67例で は16例 (23.9\%) と有意の养は認めない.

アンケート回答でも, 異常感のある15例中C M I 異常は 5 例 (33.3\%)，異常感のない57例
中異常は11例（19.3\%）で，10\%水準では有意 の差を認めない.

4. 術後 $3 \sim 6$ 週の異常感（表 6 ）

$\mathrm{A}$ a 群では術後 $3 \sim 6$ 週の診祭封に36例 (58.1\%) が異常感を訴えている. 以下 B a 群 4 例 (25.0\%), A b 群 3 例 (14.3\%), B b 群 0 例之なっている. A 群 B 群間, $\mathrm{a}$ 群 $\mathrm{b}$ 群間い ずれむ $1 \%$ 以下の伦険率で有意差を認めた。す

表 6 術後 $3 \sim 6$ 週の異常感

\begin{tabular}{lllll}
\hline & 例数 & \multicolumn{2}{c}{ 異常感あり } \\
$\mathrm{A}-[\mathrm{a}$ 群 & 62 例 & 36 例 & $(58.1 \%)$ \\
$-\mathrm{b}$ 群 & 21 & 3 & $(14.3 \%)$ \\
$\mathrm{B}-\mathrm{a}$ 群 & 16 & 4 & $(25.0 \%)$ \\
$-\mathrm{b}$ 群 & 12 & 0 & $(0.0 \%)$
\end{tabular}

表 4 契煙との関係

\begin{tabular}{|c|c|c|c|c|c|c|}
\hline & \multirow[b]{2}{*}{ 例数 } & \multirow[b]{2}{*}{ 契煙者 } & \multicolumn{2}{|c|}{ 術後 $3 \sim 6$ 速 } & \multicolumn{2}{|c|}{ アンケート回答 } \\
\hline & & & $\begin{array}{c}\text { 異常感 } \\
\text { あり }\end{array}$ & 契煙者 & $\begin{array}{c}\text { 買常感 } \\
\text { あり } \\
\text { なし }\end{array}$ & 契煙者 \\
\hline A a 群 & 59 & 38 & 36 & 25 & $\begin{array}{l}12 \\
31\end{array}$ & $\begin{array}{r}8 \\
18\end{array}$ \\
\hline A b 群 & 21 & 12 & 3 & 1 & $\begin{array}{r}1 \\
12\end{array}$ & $\begin{array}{l}1 \\
7\end{array}$ \\
\hline $\mathrm{B}$ a 碓 & 16 & 8 & 4 & 1 & $\begin{array}{l}3 \\
7\end{array}$ & $\begin{array}{l}0 \\
4\end{array}$ \\
\hline B b 群 & 12 & 5 & 0 & 0 & $\begin{array}{l}0 \\
7\end{array}$ & $\begin{array}{l}0 \\
3\end{array}$ \\
\hline
\end{tabular}

(3 例契煙歴不明)

表 5 C M I III ・ IV 領域と異常感

\begin{tabular}{|c|c|c|c|c|c|c|}
\hline & \multirow[b]{2}{*}{ 例数 } & \multirow{2}{*}{$\begin{array}{l}\text { C M I } \\
\text { III } \cdot \mathbb{I V}\end{array}$} & \multicolumn{2}{|c|}{ 術後 3 ～ 6 週 } & \multicolumn{2}{|c|}{ アンケート回答 } \\
\hline & & & $\begin{array}{l}\text { 珙常感 } \\
\text { あ }\end{array}$ & $\begin{array}{l}\mathrm{C} M \mathrm{I} \\
\mathrm{III} \cdot \mathrm{IN}\end{array}$ & $\begin{array}{c}\text { 異常感 } \\
\text { あり } \\
\text { なし }\end{array}$ & $\begin{array}{l}\text { C M I } \\
\text { III } \cdot I V\end{array}$ \\
\hline A a 群 & 61 & 21 & 36 & 11 & $\begin{array}{l}11 \\
31\end{array}$ & $\begin{array}{l}4 \\
6\end{array}$ \\
\hline $\mathrm{A} b$ 群 & 21 & 4 & 3 & 1 & $\begin{array}{r}1 \\
12\end{array}$ & $\begin{array}{l}0 \\
4\end{array}$ \\
\hline $\mathrm{B}$ a 群 & 16 & 2 & 4 & 0 & $\begin{array}{l}3 \\
7\end{array}$ & $\begin{array}{l}1 \\
1\end{array}$ \\
\hline $\mathrm{B}$ b群 & 12 & 1 & 0 & 0 & $\begin{array}{l}0 \\
7\end{array}$ & $\begin{array}{l}0 \\
0\end{array}$ \\
\hline
\end{tabular}

（1例 C M I 施行せず） 
なわち，退院後む異常感が残っている例は $\mathrm{A}$ 群，a 群に有意に多いという言うことができ

る.

5. アンケート調查の成績（表 7)

回答例での 4 群の分布は, 全症例での 4 群の 分有と有意の差はなかった。また回答のあっ た A a 群 43 例中 $3 \sim 6$ 週で異常感消失している ものは18例 (41.9\%) で，乙の值は A a 群全例 の $3 \sim 6$ 週の異常感消失率62例中26例（41.9 \%) とよく一致しているので, アンケート回答 例は全症例と差のないサンプルとして取扱うこ とにする。

アンケート調査では異常感を訴えたものは 16 例であった。 その内訳は，A群13例， B 群 3 例 ; $\mathrm{a}$ 群15例, $\mathrm{b}$ 群 1 例; 術後 $3 \sim 6$ 週の異常感 あり 8 例, なし 8 例; CM I 正常例10例, 異常 例 5 例, 不明 1 例, であった。

\section{考察}

1 ）喉頭将患による異常感は手術によって消 失するか :

対象之なった症例はいずれも喉頭マイクロ手 術を施行した症例であるので，表 3 に示す原乲 患を有している，術前に異常感を泝えていたA 群83例のうち術後巽常感の消失したのは21例 （25.3\%）であった．乙れを原它患別にみる と, ポリープは43例中14例 (32.6\%), ポリー プ椂変性は22例中 2 例 $(9.1 \%)$ で異常感が消 失した。乙の消失率には $10 \%$ 以下の危険率で有
意の差があり，ポリープ㥞変性の方が手術直後 には異常感が消失しにくいという結果である.

一方 $\mathrm{A} \mathrm{a}$ 群62例のうち26例は術後 $3 \sim 6$ 週で異 常感消失している（表 4), 残る36例中アンケ 一トに回答を笴せたのは25例で，そのうち異常 感の残っているのは僅かに 8 例であった. この 8 例の内訳はポリープ椂声师 3 例, 一側性ポリ ープ 3 例, 画側性ポリープ 1 例, 声聴チステ 1 例で, 必ずしもポリープ様声带の異常感が治り にくいとは言えない. ポリープ様声带も侍間を かければ異常感が消失するという点を考える と，ポリープ様声带の場合手術侵襲が広範囲に および治痛に侍間がかかるためと考えることが できる.

回答のなかった例む同じ制合で消失したとす ると, $\mathrm{A}$ a 群で珙常感の消失しなかった率は 18. $6 \%$ となる. すなわち術後 $3 \sim 6$ 週む異常感 が続いた例でも，さらに長い経過を見ればおよ そ80\%は異常感が消失しており，喉頭疾患が異 常感の原因的望因をなしていたてとは十分に考 えうる.

2 ) 手術により異常感がおこるか：

術前には異常感がなかったのに術後異常感を 訴えた B a 群は16例，すなわち術前に異常感の なかったB群 28 例㠷の57.1\%を占めており，喉 頭マイクロ手術が異常感発症の原因として無視 できず，原园的要国の一つであると考えるとと ができる. このB a 群16例のうち12例は術後 3

表 7 異常感の推移の還隔成績（アンケート回答例のみ）

\begin{tabular}{|c|c|c|c|c|c|c|c|}
\hline \multirow[b]{3}{*}{ A a 群 } & \multirow{2}{*}{\multicolumn{3}{|c|}{$\begin{array}{c}\text { 術後 } 3 \sim 6 \text { 週の } \\
\text { 異常感 }\end{array}$}} & \multicolumn{4}{|c|}{ アンケート時点 } \\
\hline & & & & \multirow{2}{*}{$\begin{array}{r}\text { あ } \\
8 \text { 例 } \\
4 \text { 例 }\end{array}$} & \multirow{2}{*}{$\frac{\eta}{(4)}$} & \multirow{2}{*}{ 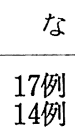 } & \multirow{2}{*}{$\begin{array}{l}\text { L } \\
(3) \\
(3)\end{array}$} \\
\hline & 43例 & $\begin{array}{l}\text { あり } \\
\text { なし }\end{array}$ & $\begin{array}{l}25 \text { 例 } \\
18 \text { 例 }\end{array}$ & & & & \\
\hline A b 群 & 13 & $\begin{array}{l}\text { あり } \\
\text { なし }\end{array}$ & $\begin{array}{r}1 \\
12\end{array}$ & $\begin{array}{l}0 \\
1\end{array}$ & & $\begin{array}{r}1 \\
11\end{array}$ & $\begin{array}{l}\text { (1) } \\
\text { (3) }\end{array}$ \\
\hline B a 群 & 10 & $\begin{array}{l}\text { あり } \\
\text { なし }\end{array}$ & $\begin{array}{l}1 \\
9\end{array}$ & $\begin{array}{l}0 \\
3\end{array}$ & (1) & $\begin{array}{l}1 \\
6\end{array}$ & (1) \\
\hline B b 群 & 7 & $\begin{array}{l}\text { あり } \\
\text { なし }\end{array}$ & $\begin{array}{l}0 \\
7\end{array}$ & $\begin{array}{l}0 \\
0\end{array}$ & & $\begin{array}{l}0 \\
7\end{array}$ & \\
\hline 合 計 & 73 & & 73 & 16 & (5) & 57 & (11) \\
\hline
\end{tabular}

（）内はCMI III - Nの例数 
〜 週の診察時には異常感は消失しており, 異 常感を訴えたのは 4 例のみであった。 ての 4 例 のうちアンケートに回答を寄せたのは 1 例のみ で，ての 1 例は異常感は消失していた。 この 4 例の内訳は結節 2 例, ロイコプラキー，ポリー プ各 1 例：男 1 例，女 3 例で, CM I 異常例は 無かった。しかし全身病として糖尿病が 2 例に みられた. 糖尿病のあったのは全部で 4 例で, 他の 2 例は A a 群で術後も異常感が消失してお らず，糖尿病は異常感の治瘾に対する遷延性要 因として注目し今後の検討が必要であろう.

アンケート回答では，A群56例中13例（23.2 \%) 飞暴常感が残っており，B群17例では 3 例 (17.6\%) 飞異常悠があり, 丽群間には有甞の 磨は認められない. しかし術後 $3 \sim 6$ 週の異常 感の訴えをみると，A群では83例中39例（47.0 \%) に，B群では28例中 4 例 (14.3\%) にみら れ，1\%以下の危険率でA群に異常感の訴えが 多いといえる。すなわち手術により唀発された と思打れる術後に生じた異常感は $3 \sim 6$ 週でほ とんど消失するが，術前からある異常感は消失 しにくく，また消失するにしても特間がかか る.

3 ）治痛を奶げると考えられる因子の検乵：

a）喫煙の影響：A 群と B 群とを比較する と，A群に喫煙の畾慣のあるあのが多いようで あるが，有意の差とは言えない，また術後に異 常感を来たした B a 群では舆煙者, 非喫煙いず れ屯 8 例で，特に器望者が術後に異常感をきた し易いとは言えない。

B a 群16例中術後 $3 \sim 6$ 週に晎常感の存在す る例は 4 例に過ぎないが，その 4 例中舆煙者は 1 例のみであり，他の 12 例中では 7 例に喫览習 憒があった，すなわち婜渱者の才が埋常感が治 りにくいという結果はみられなかった。

呢頭吹患に際して異常感を訴えるものは多い が，手術によって異常感が消失する率を，览煙 者だけについてみると A a 群38例小25例（65.8 \%)は $3 \sim 6$ 週後も晎常感を訴えているが， $\mathrm{Ab}$ 群では 12 例中 1 例 $(8.3 \%)$ B 群では13例
中 1 例（7.7\%）だけが異常感を訴えており， $\mathrm{A}$ a 群以外では喫煙が遷延性要因として働いて いるとは思えない，A a 群の非喫煙者を及る と，21例中11例（52.4\%）に異常感がのこって おり些煙者との間に有意の差を認めないので, $\mathrm{A}$ a 群に於いても喫煙が特に治痛を遷延してい るとは言えない。

アンケート時点での些煙者の比率は, 異常感 消失例で57例中 32 例 $(56.1 \%)$ ，異常感残存例

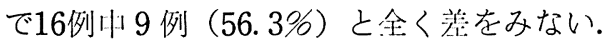

これらの検澍からみて, 何らかの原因で生じ た黑常感が消失する機転にタバコが琹影響を及 ぼしているかどうかは，非喫煙者に比して異常 感残存例が多い倾问は思られるが有意の判とは 言えない. しかし術後 $3 \sim 6$ 週の将点で $\mathrm{A}$ a 群 で異常感の消失しない例が明らかに他の群に比 して多くみられたことは，喫煙量（ブリンクマ ン指数など）との関係を調査するなど今後の検 湖に街ちたい.

b ） CM I 調查成績との関係：CM I III·IV 领域が A群に有意に多い. A a , A b 群間には 52.5\%：23.5\%と善があるようであるが，有意 の差とは言えない. A a 群内で術後 $3 \sim 6$ 週の 状況をみると, 異常感残存例36例山CM I III· IV領域を示したものは11例（30.6\%），異常感 消失例は 25 例中 10 例 $(40.0 \%$ ) と少し高率のよ うではあるが有意の差とは言えない.

アンケート時点でむ， $36.4 \%: 19.4 \%$ と異常 感残存例にCM I 異常例の率が高いが，乙れも 有意の差とは言えない.

全体としてみても最初埋常感のあった A 群は 82例中25例（30.5\%）がCM I 埋常，術後に異 常感のあった $\mathrm{a}$ 群では77例巾23例（29.9\%)， $3 \sim 6$ 週後では43例中12例（27.9\%）アンケー 卜特点では15例中 5 例（33.3\%）がCM I 異常 であり，異常感を訴える例に於けるCM I 暴常 の此率は各時点でほとんど競がない，このとと からあ遷延性要因とは言いがたい。

c ）性筀：各群ごとに男女比は表 2 に示す通 りであるが, A b 群の $14: 7$ と B a 群の $5: 11$ 
は意味がありそうに見える．しかし，全例 111 例の男女比が 60 : 51 であるので, A b 群の 14 : 7 に有意の差があるというには $30 \%$ 河の伦除率 を冒さねばならない。一方 $\mathrm{B}$ a 䂜の $5 ： 11$ は 10 \%.以下の危険率で有意の倠があると言える.す なわち術前に異常感がなくて術後に異常感を訴 えた例，换言すれば喉頭マイクロ手術によって 異常感の発来をみたといえる症例は女性のほう が多く，喉頭疾患の手術によって異常感の消失 した例は男性に多い傾向がある。

\section{結 論}

喉頭マイクロ手術を行った 111 例の術前, 術 後の異常感につき, 異常感の原因的要因之遷延 性要因について検訴した結果次の結諭を得た。

1. 矣頭疾患は異常感発来の原因的要因とな る.

2. 㗹頭マイクロ手術によりポリープによる 異常感は術後早期に消失するが，ポリープ様声 㡀による異常感は消失するのに侍間がかかる.

3. 知頭マイクロ手術の操作は異常感の原因 的要因になりうる.
4. 唝頭マイクロ手術により起こった異常感 は大半早剘に消失するが，糖尿病などが遷延性 要因になる可能性がある.

5. 術前からある異常感は術後生じた異常感 に比して消失するのに侍間がかかり，また消失 しにくい例む多い.

6. 煙草は異常感の原因的要因ではあるが, 遷延性要因とはいえない。

7. CM I の異常は啓頭娭患で異常感を訴え る例に多いが，遷延性要因とは言えない。

8. 喉頭マイク口手術のあと異常感を訴える 例は女性に多い。

9. 諮頭マイクロ手術によって術前からある 異常感が消失する例は男性に多い傾向がある.

\section{主要文献}

1) 太田文彦：咽峧頭異常感症の扱い方. 日耳鼻 $90: 1300 \sim 1303,1987$.

別刷請求先：太田文彦 T589 大阪狭山市大野東 $377-2$ 近畿大学医学部耳鼻咽喉科学教室 